Journal of Strategic Security

Volume 4

Number 2 Volume 4, No. 2, Summer

2011: Strategic Security in the Cyber

Article 13

Age

\title{
"Small Boats, Weak States, Dirty Money: Piracy and Maritime Terrorism in the Modern World," Martin N. Murphy, (New York: Columbia University Press, 2009)
}

Francis D. Bonadonna, Capt.

Chaplain Corps, U.S. Navy

Follow this and additional works at: https://digitalcommons.usf.edu/jss

Part of the Defense and Security Studies Commons, National Security Law Commons, and the Portfolio and Security Analysis Commons

pp. $133-134$

\section{Recommended Citation}

Bonadonna, Francis D. , Capt.. "'Small Boats, Weak States, Dirty Money: Piracy and Maritime Terrorism in the Modern World," Martin N. Murphy, (New York: Columbia University Press, 2009)." Journal of Strategic Security 4, no. 2 (2011) : 133-134.

DOI: http://dx.doi.org/10.5038/1944-0472.4.2.12

Available at: https://digitalcommons.usf.edu/jss/vol4/iss2/13

This Book Review is brought to you for free and open access by the Open Access Journals at Digital Commons @ University of South Florida. It has been accepted for inclusion in Journal of Strategic Security by an authorized editor of Digital Commons @ University of South Florida. For more information, please contact digitalcommons@usf.edu. 
"Small Boats, Weak States, Dirty Money: Piracy and Maritime Terrorism in the Modern World," Martin N. Murphy, (New York: Columbia University Press, 2009) 


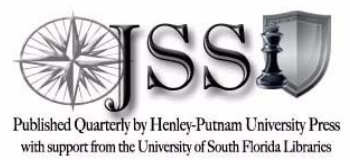

\begin{abstract}
Small Boats, Weak States, Dirty Money: Piracy and Maritime Terrorism in the Modern World. By Martin N. Murphy. New York, NY: Columbia University Press, 2009. ISBN 978-0-231-70076-4. Illustrations. Maps. Bibliographical references. Index. 539 pages. $\$ 60.00$.
\end{abstract}

Piracy is headline news. Internationally, maritime nations are struggling to find ways to effectively respond to a growing renaissance in illicit activity at sea that began in the last quarter of the twentieth century. In this book, Martin Murphy asks three questions: What is the form of contemporary piracy; what is maritime terrorism; and are these two similar or linked? He attempts to give precision to contested concepts, such as piracy, maritime terrorism, and organized crime. For example, the confusion surrounding piracy begins with definitions. The United Nations Law of the Sea Convention (UNCLOS) defines piracy as acts carried out on the high seas for private ends. This definition clouds the issue by excluding incidents that are state-sponsored, e.g., the 1975 seizure of SS Mayaguez. Further, the majority of incidents occur not on the high seas but in waters under the jurisdiction of "weak states," i.e., states unable or unwilling to protect life and property from predation. At issue is a lack of effective jurisdiction.

This book helps the uninitiated to wrestle with the issues in all their complexity. Murphy looks at the ways in which a number of factorsorganized crime, history, culture, geography, and political instabilityinteract with an environment that by its nature is anarchic and hence rife with opportunity for a variety of predators. His analysis brings to light some unexpected insights, chief among which is the essential requirement for a terrestrial component to enable piracy and maritime terrorism, for these cannot exist without a land-based infrastructure. Thus, any truly effective counter to these movements must include the denial of bases and systems ashore which dispose of and support the maritime component. The book examines issues such as the challenges in data collection, government corruption, and the use of ships as delivery systems for terrorist acts. This exhaustively researched and documented commentary is an excellent starting point for any informed and nuanced discussion of these problems.

Journal of Strategic Security 
Journal of Strategic Security

Murphy concludes that while it is a global phenomenon, piracy is not a problem everywhere, and it occurs in clusters, such as the Malacca Straits, Indonesia, and the Gulf of Aden. While at this time piracy does not have a large impact on the bulk of international commerce, when linked with transnational organized crime, it has the potential to significantly affect international security. At present, maritime terrorism has been and remains a relatively rare problem, but one that bears watching. To date, connections between pirates and terrorists have been tenuous. While similar factors affect their use of the sea, their widely divergent motivations and operations have tended to keep them apart in the past, but this could change. There is still far more to be said about these questions, but Murphy provides a treasure-house of information, analysis, and insight. This is an excellent primer!

Francis D. Bonadonna, CAPT, Chaplain Corps, U.S. Navy 